\title{
Managers in making-The Zen management way
}

\author{
Stephen D'Silva', Bernadette D'Silva² \\ (1. Jamnalal Bajaj Institute of Management Studies, Mumbai 400020, India; \\ 2. K. G. Mittal Institute of Management, Mumbai 400020, India)
}

\begin{abstract}
In the 21st century every manager in making requires a unique balance in personal, professional, family and social life so that he/she can enjoy and motivate himself to make others happy around him or her. The ego plays a major role in our life. Practicing Zen in management takes the manager to a level of egolessness. Zen finds its source in the experience of Shakyamuni Buddha, who in the process of enlightenment came across the elements of mindfulness and concentration-The noble eightfold path. These are key elements of success for the "managers in making”. The purpose of this paper consists in rethinking today's management systems in order to look for ways of management which are better adapted to human life. It is assumed that a management practice which takes into consideration of the characteristics of human life must be accepted by a large number of people and would be effective and sustainable. This paper highlights the eight elements of "The noble eightfold path" and its effective implications in management for the "managers in making” process-A guide towards success.
\end{abstract}

Key words: manager; Zen management; noble eightfold path

\section{Introduction}

Zen means a tranquil focus of the mind through meditation, concentration or dhyana (Harderwijk \& Rudy, 2006). It is a synthesis of the inner and outer reality fusing into a spontaneous flow of mind. It is deeply rooted in both the teachings of the Buddha Siddhartha Gautama and Mahayana Buddhist thought.

\subsection{What is Zen? (Bucknell, Roderick \& Stuart-Fox, Martin, 1986)}

A man comes to Bodhidharma with this question: "Why is my mind so restless? How can I set it at peace?”

Bodhidharma: "Show me your mind and I will put it at peace."

Man: "But when I search for my mind, I do not find it."

Bodhidharma: "See, I have already put it at peace."

This parable gives the simple message that if you cannot identify your mind, how it can be restless. This is the beauty of Zen-It gives you a clear understanding of self and your environment. Zen is "the way of life".

Meditation is about concentration, for developing that kind of complete awareness all the time. When meditating, one does not have to become attached to the objects of observation out of desire, or reject them from aversion. It means to become the dispassionate watcher, the one who knows: becoming Buddha (Snelling \& John, 1991). With the increasing pace of business and technology, the management problems continue to multiply. But these problems are not always bad things. In fact, if handled tactfully, the problems can be looked upon as the

Stephen D' Silva, Ph.D., director, Jamnalal Bajaj Institute of Management Studies; research fields: marketing, strategic management, services marketing.

Bernadette D’ Silva, Ph.D., director, K. G. Mittal Institute of Management; research fields: strategic management, social marketing, marketing management. 
future opportunities. Properly solving issues can increase the team motivation, cohesiveness, creativity and incentive for growth. Learning how to handle management issues is essential role of a manager.

Who don't want to be successful? Forget the highly competitive corporate world; Today even children studying in schools and colleges want success. So do folks in their own homes and societies. Workshops and seminars are conducted on how to be successful. Organizations spend huge amounts of time, money, efforts and energy in becoming successful, and making their teams successful.

\subsection{What exactly is success? And how does one really become successful?}

The parameters for success are vary from person to person. However, when learning the principles followed by great leaders, people come across some core areas and patterns on the basis of which they succeeded. These will help each one to succeed too.

Zen finds its source in the experience of Shakyamuni Buddha, who, two thousand five hundred years ago, while sitting in zazen posture under the Bodhi tree at Bodh Gaya, achieved the wake. Zazen is the return to the normal condition of body and mind. In the process of enlightenment, he came across the elements of mindfulness and concentration-The noble eightfold path (Allan \& John, 2008).

These are the key elements of success for the "manasgers in making".

As the name indicates, there are eight elements in the Noble Eightfold Path, which are divided into three basic categories as follows:

\section{Wisdom (Sanskrit: prajna)}

Buddha taught that a wise person is endowed with good bodily conduct, good verbal conduct and good mental conduct (AN3: 2), and a wise person does actions that are unpleasant to do but give good results, and doesn't do actions that are pleasant for him/her to do but give bad results (AN4: 115). Person who understands both good and evil as they really are, is called a true sage.

In an organization, a wise manager is the one:

- Who carefully discriminates between right and wrong.

- Who is an efficient communicator.

- Who strategically handles the situation. At times, the manager may be harsh with the subordinates to obtain good results.

- Who leads others by nonviolence, righteously and equitably, is indeed a guardian of justice, wise and righteous manager.

- Who is calm, free from hatred and fear.

Wisdom is looked at managers ideals and principles that govern his/her actions and decisions. Applications of personal wisdom will include his ethical and social guidelines in life that determines his unique style of personality, the particular nature of short and long-term goals pursued in life. Wisdom for a successful manager consists of making the best use of available knowledge which is achieved by right view and right intention.

In an organization, ethical manager is the one:

(1) Who is involved in planning, organizing, leading/motivating and controlling the group in ethical manner in the following way:

- Planning-Deciding what needs to happen in future and generating plans for action.

- Organizing-Making optimum use of the resources is required to enable the success. 
- Leading/Motivating-Exhibiting skills in these areas for getting others to play an effective part in achieving plans.

- Controlling-Monitoring progress against plans, which may need modifications based on feedback.

(2) Who understands his companions;

(3) Who has respect and love for peer groups;

(4) Who is a role model of honesty;

(5) Who avoids miss-conduct.

The above can be achieved by right speech, right action and right livelihood.

\subsection{Right view (samyag-drsti)}

The first factor of the path is right veiw.

According to Buddha, right view means right perspective or right understanding.

He further explains it as:

“ And what, O bhikkhus, is right understanding? To understand suffering, to understand origin of suffering, to understand extension of suffering, to understand the path leading to the extinction of suffering; this is called the right understanding”(Bogoda \& Robert, 1994; Nyanasobhano \& Bhikkhu, 1989).

What is right view for managers in making? (Bhikkhu Bodhi, 2006).

It is the knowledge with regard to stress, knowledge with regard to the origination of stress, knowledge with regard to the cessation of stress, knowledge with regard to the way of practice leading to the cessation of stress (Ñanamoli Thera \& Bhikkhu Bodhi, 1991).

Just as when a sugar cane seed, a rice grain, or a grape seed is placed in moist soil, whatever nutriment it takes from the soil and the water, all conduces to its sweetness, tasty and unalloyed delectability. Why is that? Because the seed is auspicious. In the same way, when a manager has right view, right release, whatever assignments he undertakes in line with that view, whatever verbal deeds and mental deeds he undertakes in line with that view, whatever intentions, whatever vows, whatever determinations, whatever fabrications, all lead to what is agreeable, pleasing, charming, profitable and easeful.

Why is that?

Because "the view is auspicious".

\subsection{Right intention (samma-sankappa)}

The second factor of the path is right intention.

In the analysis of this factor, Buddha explains that there are three kinds of right intentions:

(1) The intention of renunciation;

(2) The intention of non-aversion or loving kindness;

(3) The intention of non-injury or compassion.

These are opposed to the three wrong intentions - the intention of sensuality, the intention of aversion and intention of harmfulness or cruelty.

He further explains it as:

"And what is right thought? Being resolved on renunciation, on freedom from ill will, on harmlessness: This is called right thought.”

What is right intention for managers in making?

The first aspect of right intention of renunciation. Thus, managers need to understand the complete and passionless cessation of craving - giving it up, abandoning it, being released and detached from it. This is 
renunciation—giving up personal benefits, bad habits, addictions and working selflessly for the organization. Managers in making need to make an intention to change.

The second aspect of right intension is of non-aversion or loving kindness. Expressing ill will does offer some release but in the long term, it produces resentment, retaliation and enmity. These in turn produce "negative" states of mind, which then leads to inner tension, depression, self-loathing, frustration. To avoid all these issues, Managers should get rid of anger, aversion, hatred and gain good will amongst the peer group. This can be done by having a positive approach towards self as well as society.

The third aspect of right intension is of non-injury or compassion, leading to the intention to harm particularly the intention to harm another being or oneself. A common response is to blame someone else as the cause of your own suffering. The next thought is that they should be punished, harmed or got rid of. They need to see that they are imperfect and that they must change. Sometimes this view gets directed to oneself. Thus, managers in making should follow the path of "harmlessness".

\section{Ethical conduct (Sanskrit: sila)}

The non-doing of any evil, the performance of what's skillful and the cleansing of one's own mind are the teaching of the awakened (Dhammapada, 183) (Carter, John Ross \& Palihawadana, Mahinda, 1992; Kohn, Michael H, 1991).

Buddha further added that ethical conduct is built on the conception of universal love and compassion for all living beings. Compassion means love, charity, kindness, tolerance and noble qualities of emotions. Wisdom and compassion are inseparably linked together. Ethical conduct is viewed as a guideline to moral discipline, which supports the other principles of the path.

\subsection{Right speech (samyag-drsti)}

The third factor of the path is right speech.

Right speech is the first principle of ethical conduct in the eightfold path. This aspect is not self-sufficient, however, essential, because mental purification can only be achieved through the cultivation of ethical conduct.

According to Buddha, words can break or save lives, make enemies or friends, start war or create peace. He explains right speech as follows:

"And what is right speech? Abstaining from lying, abstaining from divisive speech, abstaining from abusive speech, abstaining from idle chatter.”

What is right speech for managers in making?

The managers need to:

(1) Abstain from false speech, especially not to tell deliberate lies and not to speak deceitfully;

(2) Abstain from slanderous speech and not to use words maliciously against others;

(3) Abstain from harsh words that offend or hurt others;

(4) Abstain from idle chatter that lacks purpose or depth, to tell the truth, to speak friendly, warmly and gently, and to talk only when necessary.

Thus, managers need to avoid telling lies, talking bad about anyone in any way that may bring about disharmony, hatred, anger between an individual or a group of people. Manager needs to avoid harsh, rude, impolite or abusive language, and to avoid useless gossip. If one cannot say something useful, one should keep "noble silence". 


\subsection{Right action (samyak karmanta)}

The fourth factor of the path is right action.

Right action as Buddha says is the "right conduct". It deals in a proper way in which a human being would act in his or her daily life.

And what is right action? Abstaining from taking life, from stealing and from illicit sex, this is called right action.

What is right action for managers in making?

The managers need to:

(1) Abstain from harming sentient beings, especially to abstain from taking life (including suicide) and doing harm intentionally or delinquently;

(2) Abstain from taking what is not given, which includes stealing, robbery, fraud, deceitfulness and dishonesty in the work place;

(3) Abstain from sexual misconduct.

Right action is promoting moral, honorable and peaceful conduct. Manager should abstain from destroying any kind of life, from stealing, from dishonest dealings, from illegitimate sexual intercourse and should also help others to lead a peaceful and honorable life in the right way, behaving kindly and compassionately, be honest and respect the belongings of others.

\subsection{Right livelihood (samyag ajiva)}

The fifth factor of the path is right livelihood.

A householder knowing his/her income and expenses leads a balanced life, neither extravagant nor miserly, knowing that thus his income will stand in excess of his expenses, but not his expenses in excess of his income says Buddha.

\footnotetext{
"Just as the goldsmith, or an apprentice of his, knows, on holding up a balance, that by so much it has dipped down, by so much it has tilted up; Even so a householder, knowing his income and expenses leads a balanced life, neither extravagant nor miserly, knowing that thus his income will stand in excess of his expenses, but not his expenses in excess of his income."

"And what is right livelihood? There is the case where a disciple of the noble ones, having abandoned dishonest livelihood, keeps his life going with right livelihood. This is called right livelihood.”
}

What is right livelihood for managers in making?

The managers need to avoid:

(1) Dealing in weapons;

(2) Dealing in living beings (including raising animals for slaughter as well as slave trade and prostitution);

(3) Dealing in occupation that would violate the principles of right speech and right action.

The managers in making should abstain from making a living through a profession that brings harm to others. They should live by a profession that is honorable, blameless and innocent of harm to others.

Managers need to possess the basic three qualities—right view, right effort and right mindfulness.

\section{Mental discipline (sanskrit-samadhi)}

Samadhi means concentration. One can achieve Samadhi through mental discipline and meditation of a very high standard. When you prevent the mind from following its usual habits, it will resist and complain with restlessness, laziness or doubts. Like a spoiled child who is made to sit still, the fickle mind will struggle to escape from the confines of continuous mindfulness. 
The "mental discipline" is constituted by those elements that deal with how a Buddhist practitioner can best go about shaping his or her outlook towards the world, says Buddha (Niimi, J., 2006).

In organization, disciplined manager is the one

- Who gives systematic instruction to his team;

- Who clearly understands the difference between disipline and punishment;

- Who creates a situation which encourages the staff member to work with him to identify causes of problematic behavior, and to take action to correct those problems;

- Who desires to have harmony in organization.

Mental discipline depends on right effort, right mindfulness, and right concentration.

\subsection{Right effort (samyag vyayama)}

The sixth factor of the path is right effort.

The "right effort" element refers to the process of attempting to root out an ill wish and replace it with a good wish.

Right effort can be seen as a prerequisite for the other principles of the path. Without effort, which is in itself an act of will, nothing can be achieved, whereas misguided effort distracts the mind from its task and confusion will be the consequence. Mental energy is the force behind right effort. It can occur in either wholesome or unwholesome states.

What, monks, is right effort?

(1) There is the case where a monk generates desire, endeavors, activates persistence, upholds and exerts his intent for the sake of the non-arising of evil, unskillful qualities that have not yet arisen.

(2) He generates desire, endeavors, activates persistence, upholds and exerts his intent for the sake of the abandonment of evil, unskillful qualities that have arisen.

(3) He generates desire, endeavors, activates persistence, upholds and exerts his intent for the sake of the arising of skillful qualities that have not yet arisen.

(4) He generates desire, endeavors, activates persistence, upholds and exerts his intent for the maintenance, non-confusion, increase, plenitude, development, \& culmination of skillful qualities that have arisen. This is called right effort.

What is right effort for managers in making?

Right effort is detailed in four types of endeavours that rank in ascending order of perfection. Managers need to:

(1) Prevent the arising of unseen situations, which could be the future risk for the organization;

(2) Abandon evil, unethical behavior that have already arisen;

(3) Arouse new ideas and motivate and respect subordinates to come up with suggestions;

(4) Maintain the quality of team and motivate them by offering monetary and non monetary benefits.

Thus, right effort is the energetic will of a manager to prevent evil and unwholesome states of mind from arising, to get rid of such states have they already arisen, to produce good and wholesome states of mind, and to develop and bring to perfection those good states.

\subsection{Right mindfulness (samyak smrti)}

The seventh factor of the path is right mindfulness.

According to Buddha, right mindfulness is also termed as right memory, together with right concentration. Mindfulness refers to the practice of keeping the mind alert to phenomena as they are affecting the body and mind.

"And what is right mindfulness? There is the case where a monk remains focused on the body in and of itself: ardent, alert and mindful, putting aside greed and distress with reference to the world. He remains focused on feelings in and of 
themselves. The mind in and of itself. Mental qualities in and of themselves: ardent, alert and mindful. This is called right mindfulness."

Right mindfulness is the controlled and perfected faculty of cognition. This mindfulness or the enlightenment or awareness of the things we do everyday, according to the Buddha, is to live in the present moment, to live in the present action. This is also the Zen way. In this form of meditation, one does not have to do anything specific to develop mindfulness. One must be mindful of everything one does (Rahula \& Walpola, 1974). It is the mental ability to see things as they are, with clear consciousness. All this happens only half consciously, and as a result, we often see things obscured. Right mindfulness is anchored in clear perception, and it penetrates impressions without getting carried away. It enables us to be aware of the process of conceptualization in a way that we actively observe and control the way our thoughts go. It means developing a full consciousness about yourself (Niimi, 2006).

Buddha accounted for this as the four foundations of mindfulness:

(1) Contemplation of body;

(2) Contemplation of feeling (repulsive, attractive, or neutral);

(3) Contemplation of the state of mind;

(4) Contemplation of the phenomena.

So what is right mindfulness for managers in making?

Managers need to follow the 6 steps to achieve right mindfulness in the organization:

(1) assuming difference;

(2) knowing self;

(3) suspending self;

(4) allowing guided imagination;

(5) allowing empathic experience;

(6) reestablishing self.

Thus, the manager should be always aware, mindful and attentive with regard to the activities of the body, the sensations or feelings, the activities of the mind and ideas, thoughts, conceptions and things of that nature. These aspects affect the efficiency, and thus affecting the productivity of individual.

\subsection{Right concentration (samyak samadhi)}

The eight factor of the path is right concentration.

Right concentration means establishing the mind rightly. On one level, this can apply to all the factors of the path. You have to start out by setting the mind on right view, setting the mind on right resolve, says Buddha.

"And what is right concentration? There is the case where a monk-quite withdrawn from sensuality, withdrawn from unskillful (mental) qualities enters and remains in the first jhana: rapture and pleasure born from withdrawal, accompanied by directed thought and evaluation. With the stilling of directed thoughts and evaluations, he enters and remains in the second jhana: rapture and pleasure born of composure, unification of awareness free from directed thought and evaluation -internal assurance. With the fading of rapture, he remains in equanimity, is mindful and alert, and senses pleasure with the body. He enters and remains in the third jhana, of which the noble ones declare, he has a pleasurable abiding. With the abandoning of pleasure and pain as with the earlier disappearance of elation and distress he enters and remains in the fourth jhana: purity of equanimity and mindfulness, neither pleasure nor pain. This is called right concentration.” (Thanissaro Bhikkhu, 1996).

What is right concentration for managers in making?

The managers need to:

- Use right speech, as communication forms the base of effective manager; 
- Set right action and keep them firmly in line with what is right;

- Set mind on providing for healthy livelihood exclusively in a right way;

- Always remain alert;

- Keep self updated with latest happenings in the organization.

A sharp person knows how to differentiate between ordinary men and great men. And if a manager can successfully inculcate this quality, he can easily become successful in all walks of life. Just like a jeweler, who should have the knack of identifying "rare” gems from ordinary stones.

\section{Conclusion}

Recent studies in management strategies have revealed that profit alone is not the be-all and end-all of an organization. The strategic direction of management really pertains to focusing the mind of managers. The mechanistic framework of an organization and its resources are mere materials to be manipulated or utilized by the direction of its people's minds. Those who talk of software, hardware, competitive strategies, learning organization or self-organization are really referring to new directions of the mind. At the same time, they are also referring to a change in focus. By employing a focused mind, you become aware of new paths. And, finally, this becomes a natural way of behavior and action for a manager.

Given a pace at which business operates, management assumes greater relevance. Management related problems multiply all the time. Handled tactfully, the problems can be transformed into opportunities. A leader must live in tune with the organization, and the cosmic world where interdependence, networking and awareness of being part of the whole are vital. An effective manager of the future will see his role as a cosmic performer, part of the flux that flows through business and life, and finally discover joy for himself as well as others in society. Thus, an ordinary person by following the "noble eightfold path" can become a successful manager not only in his professional life but also at personal level.

\section{References:}

Allan, J.. (2008). The eight-fold path. Retrieved March 6, 2008, from http://www.buddhanet.net/e-learning/8foldpath.htm.

Bodhi, B.. (2006). The noble eightfold path: The way to the end of suffering. Washington: Pariyatti Publishing.

Bogoda, R.. (1994). A simple guide to life. Retrieved February 4, 2008, from http://www.accesstoinsight.org/lib/authors/bogoda/ wheel397.html.

Bucknell, R. \& Stuart-Fox, M.. (1986). The twilight language: Explorations in Buddhist meditation and symbolism. London: Curzon Press.

Carter, J. R. \& Palihawadana, M.. (1992). Buddhism: The dhammapada. New York: History Book Club.

Harderwijk, R.. (2006). A view on Buddhism: Mind and mental factors. Retrieved July 4, 2006, from http://buddhism. kalachakranet.org/mind.html.

Kohn, M. H.. (1991). The Shambhala dictionary of Buddhism and Zen. Boston: Shambhala.

Thera, Ñ. \& Bodhi, B. (ed.). (1991). The discourse on right view: The Sammaditthi Sutta and its commentary. Kandy: Buddhist Publication Society. Retrieved September 22, 2007, from http://www.accesstoinsight.org/lib/authors/nanamoli/ wheel377.html.

Niimi, J.. (2006). Buddhism and cognitive science. Retrieved July 8, 2006 from http://home.uchicago.edu/ jniimi/buddcogsci/ paper.html.

Nyanasobhano, B.. (1989). Two dialogues on Dhamma. Kandy: BPS. Retrieved February 4, 2008, from http://www. accesstoinsight.org/lib/authors/price/wheel363.html.

Rahula, W.. (1974). What the Buddha taught. New York: Grove Press.

Dhamma, R.. (1997). The first discourse of the Buddha. Somerville, Massachusetts: Wisdom Publications.

Snelling, J.. (1991).The Buddhist handbook: A complete guide to Buddhist schools, teaching, practice, and history. Rochester: Inner Traditions.

Bhikkhu, T.. (1996). Magga-vibhanga Sutta: An analysis of the path. Retrieved June 25, 2006, from http://www. accesstoinsight.org/ tipitaka/sn/sn45/sn45.008.than.html. 